\title{
EFEKTIVITAS PENAMBAHAN EKSTRAK MESOCARP Borassus flabellifer PADA PENGENCER BELTSVILLE THAWING SOLUTION TERHADAP VIABILITAS SPERMATOZOA ASAL KAUDA EPIDIDIMIS BABI
}

\section{Effectiveness of Borassus flabellifer Mesocarp Extract in Beltsville Thawing Solution Diluents on Spermatozoa Viability from Swine Cauda Epididymis}

\author{
Hermilinda Parera ${ }^{1}$, Bernadus Ndoen $^{1}$, Victor Lenda $^{1}$, Muhammad Mirandy Pratama Sirat $^{2}$ \\ ${ }^{1}$ Department of Veterinary Science, Politeknik Pertanian Negeri Kupang \\ Jl. Prof DR Herman Yohanes Lasiana Kupang \\ ${ }^{2}$ Department of Animal Husbandry, Faculty of Agriculture, University of Lampung \\ Jl. Soemantri Brojonegoro No. 1, Gedong Meneng, Rajabasa, Bandar Lampung 35145 \\ E-mail: milindaparera81@gmail.com
}

\begin{abstract}
This study aimed to determine the effectiveness of adding various concentrations of palm fruit mesocarp (Borassus flabellifer) extract to Beltsville Thawing Solution (BTS) diluents on the viability of swines cauda epididymis spermatozoa at $13^{\circ} \mathrm{C}$ for 4 days. During the storage period, the metabolic activity of spermatozoa will produce free radicals which can reduce spematozoa viability. Borassus flabellifer mesocarp extract contains antioxidants that can counteract free radicals. Testicular and epididymal samples from the 3-4 years old Duroc Landrace Swine Crossbreed. Swine cauda epididymis were obtained from the Oeba Abattoir, Kupang. Cauda epididymis spermatozoa were collected using a combination of incision, rinsing and suppression methods then collected and diluted using BTS and divided into four groups to be given various concentrations of Borassus flabellifer mesocarp extract (K0: without extract; K1: 0.01\%; K2: 0.03\%; and K3: $0.05 \%$ ) and preserved at $13{ }^{\circ} \mathrm{C}$ for 4 days. Evaluation of spermatozoa viability was carried out microscopically. The results of cauda epididymis sperm viability were KO= 43.57\%; K1 = 54.81\%; K2 = 50.52\%; and K3 = 49.95\%. Analysis of variance showed that the addition Borassus flabellifer mesocarp extract gave a significant difference $(P>0.05)$ to spermatozoa viability. The Duncan region test showed a significant difference $(P<0.05)$ between treatment $K 1$ with treatments KO, $K 2$ and $K 3$ on the viability of spermatozoa. The conclusions of this study was the addition of Borassus flabellifer mesocarp extract at $0.01 \%$ concentration was the most appropriate dose to maintain the viability of swine cauda epididymis spermatozoa.
\end{abstract}

Keywords: Borassus flabellifer, Cauda Epididymal, Mesocarp Extract, Spermatozoa, Swine.

\section{PENDAHULUAN}

Usaha pengembangan peternakan di daerah Nusa Tenggara Timur (NTT) terus dilakukan mengingat NTT memiliki potensi alam peternakan yang cukup besar untuk dikembangkan seperti ternak babi. Upaya yang dilakukan untuk meningkatkan populasi ternak babi dengan terus menerapkan berbagai kemajuan teknologi. Teknologi reproduksi yang sampai saat ini masih digunakan adalah inseminasi buatan (IB). Inseminator babi di Kupang masih menggunakan semen segar yaitu semen yang ditampung dari pejantan, dikemas dalam botol dan dibawa ke lokasi untuk langsung digunakan dalam pelayanan inseminasi buatan. Semen segar ini tidak dapat bertahan lama lebih dari 24 jam, sehingga setiap akan melakukan pelayanan IB maksimal 1 jam sebelumnya dilakukan penampungan semen. Pengunaan semen segar dalam waktu yang lama memerlukan preservasi dengan pengencer dan temperatur tertentu agar motilitas dan daya hidup spermatozoa tetap terjaga. Semen babi berbeda dengan semen ternak lain karena semen babi sangat sensitif terhadap cold shock. Inovasi baru diperlukan dalam bidang reproduksi untuk mempertahankan kualitas semen yang dapat disimpan pada suhu lemari es, sehingga penampungan semen tidak dilakukan setiap akan memberikan pelayanan IB. Selama 
proses penyimpanan pada suhu dingin di samping mengalami kejutan dingin, spermatozoa juga mengalami stres oksidatif atau terjadi serangan Reactive Oxygen Species (ROS), maka dalam pengencer perlu ditambahkan antioksidan.

Sumber antioksidan dapat diperoleh dari beberapa tumbuhan baik pada buah, akar maupun daunnya. Buah lontar merupakan tanaman khas yang banyak tumbuh di kabupaten Kupang berasal dari spesies Borassus flabellifer Linn. Buah lontar mengandung karbohidrat, protein, tanin, karotanoid. Senyawa B karoten 6217,48 $\mu \mathrm{g} / 100 \mathrm{~g}$ (Idayati et al., 2014). Menurut Pryor et al., (2000) B karoten merupakan salah satu senyawa yang memiliki kemampuan kerja sebagai senyawa antioksidan yang baik. Antioksidan sangat penting untuk menurunkan ROS yang dihasilkan oleh sel termasuk sel sperma yang dapat menyebabkan kerusakan sel. Spermatozoa babi sangat rentan terhadap ROS karena ROS dapat merangsang reaksi akrosom dalam babi sperma melalui peroksidasi lipid membran dan aktivasi PLA (Basim et al., 2009).

Sumber spermatozoa alternatif dapat diperoleh dari epididimis yang merupkan limbah rumah potong hewan karena memiliki kemampuan membuahi oosit yang sama dengan spermatozoa hasil ejakulasi karena spermatozoa asal kauda epididimis memiliki motilitas, integritas membran plasma dan morfologi yang tidak berbeda dengan spermatozoa ejakulasi. Spermatozoa dari kauda epididimis tetap hidup dengan kualitas yang baik untuk jangka waktu antara 10-20 jam postmortem (Martinez-Pastor et al., 2006).

Pengenceran semen dapat mengunakan bahan-bahan tertentu yang mampu memberi makanan dan memperpanjang masa hidup spermatozoa diluar tubuh. pengencer yang digunakan adalah Beltsville Thawing Solution (BTS). Selama pengolahan dan penyimpanan semen, spermatozoa akan mengalami proses metabolisme seperti sel lainnya untuk mempertahankan hidupnya spermatozoa akan menghasilakan energi juga menghasilkan radikal bebas melalui reaksi peroksidasi lipid yang dapat merusak membran spermatozoa (Zaniboni et al., 2006). Upaya untuk menghambat terjadinya kerusakan membran atau meminimalkan kerusakan membran sperma akibat peroksidasi lipid melalui pemberian selama proses penyimpanan dapat dilakukan dengan penambahan antioksidan dalam pengencer. Berdasarkan latar belakang tersebut, perlu dikaji lebih mendalam manfaat penambahan ekstrak mesocarp buah lontar terhadap daya hidup (viabilitas) spermatozoa asal kauda epididmis babi.

\section{MATERI DAN METODE}

\section{Koleksi dan Pengolahan Spermatozoa}

Spermatozoa epididimis diperoleh dari testis yang merupakan limbah rumah pemotongan hewan Kupang. Koleksi semen dilakukan dengan cara slicing bagian cauda epididimis sedemikian rupa sehingga semen pada bagian cauda tersebut akan keluar. Epididimis dipisahkan dari testis dan dibilas dengan larutan $\mathrm{NaCl}$ fisiologis yang telah diberi 213iltrate213c $(0,9 \% \mathrm{NaCl})$, kemudian kauda dipisahkan dari kaput dan korpus epididimis. Spermatozoa dikoleksi dengan cara membuat sayatan-sayatan pada kauda epididimis kemudian dibilas dengan larutan pengencer dengan penekanan bilas tekan (Rizal, 2005). Sebelum dibilas, tekan dengan larutan pengencer, spermatozoa disedot dengan pipet eritrosit untuk dihitung konsentrasinya. Spermatozoa hasil koleksi diencerkan dengan pengencer sesuai perlakuan. Pengencer yang digunakan adalah pengencer Beltsville Thawing Solution (BTS) dan pengencer tris sitrat fruktosa.

\section{Pembuatan Ekstrak}

Mesocarp buah lontar (Borassus flabellifer) sebanyak $2 \mathrm{~kg}$ dikeringkan pada oven dengan suhu $70^{\circ} \mathrm{C}$, kemudian sampel dimaserasi selama 24 jam menggunakan pelarut ethanol setelah itu disaring, filtrat yang diperoleh di evaporasi sampai diperoleh ekstrak kental sebanyak $200 \mathrm{~mL}$, kemudian diencerkan sesuai kebutuhan.

\section{Variabel Kualitas Spermatozoa}

Kualitas spermatozoa dievaluasi setelah koleksi (spermatozoa segar) serta setelah pengenceran dan preservasi. Kualitas spermatozoa yang dievaluasi pada tahap spermatozoa segar secara makroskopis yaitu warna dan derajat keasaman. Evaluasi terhadap spermatozoa yang telah diencerkan dan dipreservasi yaitu evaluasi terhadap persentase daya hidup spermatozoa

\section{Analisis Data}

Data hasil pengamatan secara makroskopis (warna dan $\mathrm{pH}$ ) ditabulasi dan selanjutnya dianalisis menggunakan rata-rata serta diulas secara deskriftif, sedangkan data persentase viabilitas spermatozoa dianalisis secara kuantitatif menggunakan two way analysis of varians (ANOVA) dengan metode analisis regresi linear sederhana (Steel and Torrie, 1993). 


\section{HASIL DAN PEMBAHASAN}

\section{Karekteristik Spermatozoa Kauda Epididimis Babi}

Hasil penelitian menunjukan secara makroskopis spermatozoa berwarna putih susu, konsistensi encer (Gambar 1) dengan derajat keasaman atau $\mathrm{pH} \pm 7$. Gadea (2003) mengatakan $\mathrm{pH}$ semen babi $7,4 \pm 0,2$. Faktor-faktor yang mempengaruhi $\mathrm{pH}$ adalah umur, tingkat rangsangan, frekuensi ejakulasi, lingkungan dan kualitas pakan (Johnson et al., 2000 dan Feradis, 2010). Rataan konsentrasi spermatozoa pada kauda epididimis babi adalah 280-300 × $10^{6}$. Konsentrasi spermatozoa akan semakin meningkat setelah memasuki cauda epididimis, yakni sebesar $10-50 \times 10^{9}$ serta memiliki motilitas dan kemampuan membuahi oosit yang kurang lebih sama dengan spermatozoa hasil ejakulasi (Senger, 1999). Rataan motilitas spermatozoa yang diperoleh pada penelitian ini yaitu $79,00 \pm 2,74 \%$ dan masih berada pada kisaran persentase motilitas spermatozoa hasil penelitian Garner dan Hafez (2000) yaitu 80\%.

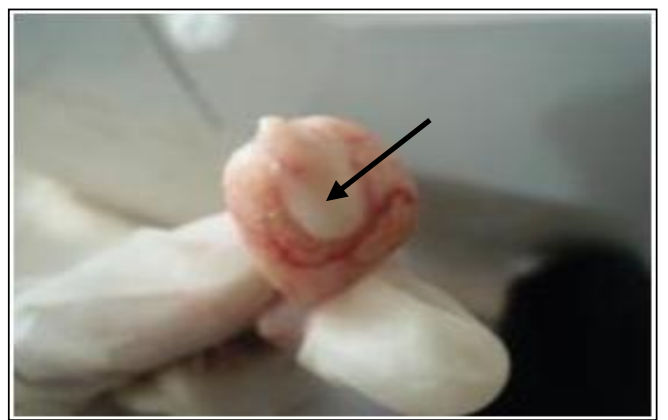

Gambar 1. Konsistensi encer dan warna putih spermatozoa (tanda panah) asal kauda epididimis babi

Faktor-faktor yang mempengaruhi motilitas spermatozoa adalah bangsa, individu, umur ternak, jumlah ejakulat dan perubahan temperatur (Shukla et al., 1992; Johnson et al., 2000). Persentase abnormal spermatozoa (Gambar 2) hasil penelitian tergolong rendah yaitu $11,5 \pm 2,33 \%$ dan berada jauh dibawah standar maksimal abnormalitas yang dianjurkan yaitu 20\% (Garner dan Hafez 2000; Johnson et al., 2000).

Berdasarkan data sifat-sifat fisik spermatozoa segar epididimis babi yang diperoleh (Tabel 1) menunjukkan bahwa spermatozoa tersebut memiliki kualitas yang baik dan memenuhi syarat untuk diproses lebih lanjut, baik dalam bentuk semen cair-dingin maupun semen beku. Hal tersebut karena spermatozoa segar memiliki persentase rataan spermatozoa motil $79,00 \pm 2,74 \%$ dan spermatozoa abnormal $11,5 \pm 2,33 \%$. Menurut beberapa peneliti, semen segar yang baik harus memiliki persentase spermatozoa motil 70\% (Evans dan Maxwell, 1987), persentase spermatozoa abnormal $20 \%$ (Garner dan Hafez 2000; Johnson et al., 2000), dan persentase Membran Plasma Utuh (MPU) 60\% (Revell dan Mrode, 1994).

Tabel 1. Sifat fisik spermatozoa segar epididimis babi

\begin{tabular}{lc}
\hline \multicolumn{1}{c}{ Variabel } & Rataan \\
\hline $\begin{array}{l}\text { Konsentrasi } \\
\text { Spermatozoa }\end{array}$ & $280-300 \times 10^{6} / \mathrm{ml}$ \\
$\begin{array}{l}\text { Motilitas } \\
\text { spermatozoa }\end{array}$ & $79,00 \pm 2,74 \%$ \\
$\begin{array}{l}\text { Abnormalitas } \\
\text { spermatozoa }\end{array}$ & $11,5 \pm 2,33 \%$ \\
\hline
\end{tabular}

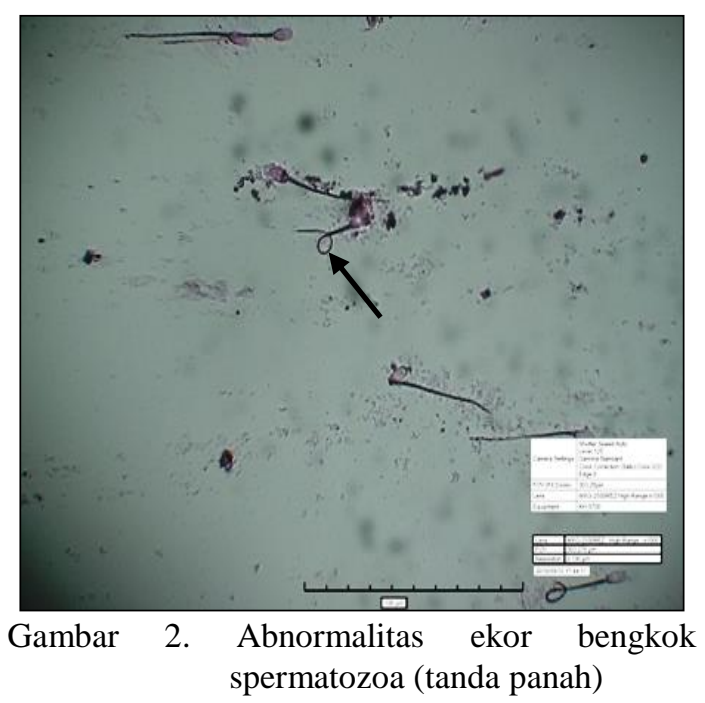

Tabel 2. menunjukan hasil analisis varian terdapat interaksi yang sangat nyata $(\mathrm{P}<0,01)$ antara konsentrasi ekstrak mesoarp buah lontar dengan jangka waktu penyimpanan terhadap viabilitas spermatozoa asal cauda epididmis babi yang disimpan pada suhu $13^{\circ} \mathrm{C}$. Dimana semakin lama penyimpanan semakin rendah viabilitas (daya hidup) spermatozoa cauda epididmis babi atau semakin lama penyimpanan daya hidup sperma makin rendah. Lama penyimpanan menyebabkan proses metabolisme terganggu akibat menurunnya produksi energi berupa ATP, sehingga menurunkan motilitas dan daya hidup spermatozoa. Lama waktu penyimpanan spermatozoa berpengaruh terhadap daya hidup 
spermatozoa, semakin lama waktu penyimpanan maka daya hidup spermatozoa semakin menurun disebabkan karena selama penyimpanan, spermatozoa tetap melakukan metabolisme yang menghasilkan reaksi oksidatif (Bebas et al., 2015)

Tabel 2. Analisis variasi lama penyimpanan dengan konsentrasi ekstrak buah lontar.

\begin{tabular}{cc}
\hline $\begin{array}{c}\text { Lama Preservasi } \\
\text { (Hari) }\end{array}$ & $\begin{array}{c}\text { Viabilitas } \\
\text { (Daya Hidup) }\end{array}$ \\
\hline 1 & $81,17^{\mathrm{f}}$ \\
2 & $79,92^{\mathrm{f}}$ \\
3 & $68,50^{\mathrm{e}}$ \\
4 & $55,50^{\mathrm{d}}$ \\
5 & $37,25^{\mathrm{c}}$ \\
6 & $18,75^{\mathrm{a}}$ \\
7 & $6,92^{\mathrm{b}}$ \\
\hline
\end{tabular}

Keterangan: Huruf yang berbeda kearah kolom menunjukan perbedaan yang nyata lama penyimpanan $(\mathrm{P}<0,05)$

Pada saat proses pengenceran dan penyimpanan semen babi sangat peka terhadap perubahan temperatur karena lapisan lipid pada membran spermatozoa babi sangat tipis sehingga spermatozoa babi tidak tahan pada suhu rendah. Metabolisme spermatozoa selama penyimpanan akan menghasilkan reaksi antara spermatozoa dengan oksigen yang akan menyebabkan terbentuknya radikal bebas. Radikal bebas yang terbentuk akan memicu terjadinya peroksidasi lemak membran sehingga akan menurunkan daya hidup dan motilitas spermatozoa (Sikka, 1996).

Tabel 3. Uji Duncan Konsentrasi Ekstrak mesocarp buah lontar terhadap Viabilitas Spermatozoa cauda epididimis babi

\begin{tabular}{lccc}
\hline \multirow{2}{*}{ Konsentrasi Ekstrak } & \multicolumn{3}{c}{ Subset } \\
\cline { 2 - 4 } & $\mathbf{1}$ & $\mathbf{2}$ & $\mathbf{3}$ \\
\hline Kontrol (K0) & $43.57^{\mathrm{a}}$ & \\
$0,05 \%(\mathrm{~K} 3)$ & & $49.95^{\mathrm{a}}$ & \\
$0,03 \%(\mathrm{~K} 2)$ & & $50.52^{\mathrm{a}}$ & \\
$0,01 \%(\mathrm{~K} 1)$ & & & $54.81^{\mathrm{b}}$ \\
\hline Sig. & 1.000 & .756 & 1.000 \\
\hline
\end{tabular}

Adanya perbedaan yang nyata $(\mathrm{P}<0,05)$ antara perlakuan $\mathrm{K} 1$ dengan perlakuan $\mathrm{K} 0$, K2 dan K3 terhadap viabilitas spermatozoa asal cauda epididmis babi yang disimpan pada suhu $13^{\circ} \mathrm{C}$. Uji Duncan pada Tabel 3 menunjukkan bahwa viabilitas spermatozoa dengan penambahan ekstrak mesocarp buah lontar pada K1 lebih tinggi dari K0, K2, dan K3 $(\mathrm{P}<0.05)$. Antioksidan yang terkandung dalam ekstrak mesocarp buah lontar berupa vitamin $\mathrm{C}$, alkaloid, tanin, dan flavanoid dapat dapat mengikat oksigen radikal yang terdapat didalam sel, sehingga dapat mencegah terjadinya reaksi peroksidasi lipid yang dapat menurunkan daya hidup spermatozoa (Aurich et al., 1997). Pemberian konsentrasi ekstrak mesocarp buah lontar sebagai sumber antioksidan yang tepat, akan memberikan hasil yang maksimal dalam memutus reaksi rantai peroksidasi lipid pada membran spermatozoa (Bebas et al., 2015)

Pada perlakuan K2 dan dan K3 daya hidup spermatozoa lebih rendah secara nyata $(\mathrm{P}<0,05)$ dibandingkan perlakuan K1. Hal ini mmbuktikan semakin tinggi konsentrasi ekstrak mesocarp buah lontar dalam pengencer semen BTS dapat mempersingkat daya tahan hidup spermatozoa asal cauda epididmis babi selama penyimpanan $13^{\circ} \mathrm{C}$. Rahardianto et al. (2012) menyatakan bahwa pemberian larutan dengan konsentrasi yang lebih besar tidak sesuai sebagai media hidup karena sel spermatozoa hanya dapat melakukan metabolisme secara maksimal bila pengencer bersifat isotonik. Penambahan konsentrasi ekstrak mesocarp buah lontar akan mempertinggi konsentrasi alkaloid dan tanin dalam pengencer. Alkaloid dapat mengganggu aktivitas ATP-ase pada membran sel spermatozoa dibagian ekor. ATP-ase tersebut berfungsi mempertahankan homeostatis internal untuk ion natrium dan kalium. Jika aktivitas ATP-ase terganggu, maka homeostatis ion natrium dan kalium akan terganggu sehingga konsentrasi $\mathrm{Na}^{+}$intrasel meningkat, gradien $\mathrm{Na}^{+}$melintasi membran sel akan mengalami penurunan (Ganong, 2001). Jika permeabilitas membran spermatozoa terganggu akan menyebabkan terganggunya transport nutrisi yang diperlukan oleh spermatozoa untuk bertahan hidup dan pergerakannya (Salisbury dan Ross, 1995)

\section{SIMPULAN DAN SARAN}

\section{Simpulan}

Simpulan penelitian ini adalah penambahan berbagai konsentrasi ekstrak mesocarp buah lontar (Borassus flabellifer) dan lama penyimpanan berpengaruh nyata $(\mathrm{P}<0.05)$ terhadap daya hidup spermatozoa asal cauda epididimis babi. Konsentrasi ektrak mesocarp buah lontar $0,01 \%$ memberikan viabilitas spermatozoa asal kauda epididimis babi lebih tinggi dibandingkan kontrol, konsentrasi $0,03 \%$ dan $0,05 \%$. 


\section{Saran}

Perlu dilakukan penelitian lebih lanjut untuk mengatahui kemampuan fertilisasi menggunakan semen cauda epididimis babi yang diberi pengencer Beltsville Thawing Solution (BTS) dan ekstrak mesocarp buah lontar (Borassus flabellifer) konsentrasi 0,01\%.

\section{UCAPAN TERIMA KASIH}

Penulis mengucapkan terima kasih kepada drh Vitri Ayu Kusuma dan Pihak Rumah Potong Hewan Kupang, Kepala Laboratorium Kesehatan Hewan Politani Kupang dan Teknisi Yonas Lino, Alumni mahasiswa D3 Kesehatan Hewan Politani Kupang; Maria Niron, Lidersia Seu, Fransiskus Umbu Windi, Mateus Mado yang telah membantu penelitian ini, serta semua pihak yang telah berpartisipasi dalam penelitian ini.

\section{DAFTAR PUSTAKA}

Aurich, J.E., U.S.H. Hoppe, and C. Aurich. 1997. Effect of antioxidants on motility and membrane integrity of chilled stored stallition semen. Theriogenology. 40: 841 85.

Awda, Basim J., M. Mackenzie-Bell, M.M. Buhr. 2009. Reactive Oxygen Species and Boar Sperm Function. Biol. Reprod. 81: 553561

Bebas W, Budiasa M K dan Ika Y Astutik. 2015. Penambahan Viatmin C pada Pengencer Spermatozoa Babi Landrace yang di simpan pada suhu $15^{\circ} \mathrm{C}$. Bul. Vet. Udayana. 7(2): 179-185

Evans G, Maxwell WMC. 1987. Salamon's Artificial Insemination of Sheep and Goats. Butterworths. London.

Feradis. 2010. Bioteknologi Reproduksi pada Ternak. Alfabeta. Bandung

Gadea, J. 2003. Pig Industry-Semen Extenders Used in the Artificial Insemination of Swine. A Review. Spanish J. Agric. Research 1(27): 17-27

Ganong, W.F. 2001. Buku Ajar Fisiologi Kedokteran. Buku Kedokteran EGC, Jakarta.

Garner, D.L dan Hafez, E.S.E., 2000. Spermatozoa and seminal plasma. Dalam: Reproduction in Farm Animals. B.Hafez/E.S.E. Hafez, Edisi ke 7. Lippincott Williams \& Wilkins, Philadelphia. P : 165-167.
Hafez, E.S.E. dan B. Hafez. 2000. Reproduction in Farm Animal, 7th edition. Baltimore : Lippicott Williams and Wilkins.

Idayati, E., Suparmo., Purnama D. 2014. Potency of Mesocarp Bioactive Compounds in Lontar Fruit (Borassus fl abeliffer L.) as A Source of Natural Antioxidant. Journal Agritech, 34:3

Johnson, L.A., K.F. Weitze, P. Fiser, W.M.C. Maxwell. 2000. Storage of Boar Semen. J. Anim. Sci. 62: 143-172

Martinez-Pastor, F., F. Martinez, V.G. Macias, M.C. Esteso, E. Anel, R. M.R.F. Santos, A.J. Soler, P. De Paz, J. Garde and L. Anel. 2006. A pilot study on post thawing quality of Iberian red deer spermatozoa (epididymal and electroejaculated) depending on glycerol concentration and extender osmolality. Theriogenology 66: $1165-72$

Pryor WA., Stahl W., Roch CL. 2000. B-carotene From Biochemistry to Clinical Trials Nutr.Rev.58:39-53.

Revell SG, Mrode RA. 1994. An osmotic resistance test for bovine semen. Anim Reprod Sci 36: 77-86.

Rizal M. 2005. Efektivitas Berbagai Konsentrasi ß-Karoten terhadap Kualitas Semen Beku Domba Garut. Animal Production, Vol.7, No. 1 Januari 2005:6-13.

Salisbury, B. dan C.W. Ross. 1995. Fisiologi Tumbuhan. Jilid 1. Edisi IV. ITB, Bandung.

Senger, P.L. 1999. The organization and function of the male reproduction system. In : Pathways to Pregnancy and Parturition. Current Conception, Inc., Pullman. Pp.. 32-57.

Shukla, S.N., B.B. Singh, N.S. Tomar and B.S. Misra. 1992. Factors Affecting Prematozoon Motility in Preserved Semen. Indian Vet J. $69: 856-857$

Sikka SC. 1996. Oxidative Stress and Role of Antioxidant in Normal and Abnormal Sperm Function. Frontiers in Bioscience; 78-86 August 1.

Steel, R.G.D. dan Torrie, J.H. (1993). Prinsip dan Prosedur Statistika, Suatu Pendekatan Biometrik. Alih bahasa: B. Sumantri. Gramedia Pustaka Utama. Bogor.

Zaniboni, L., R. Rizzi and S. Cerolini. 2006. Combined effect of DHA and $\alpha$ tocopherol enrichment on sperm quality and fertility in the turkey. Theriogenology. 65 (1): 18131827. 